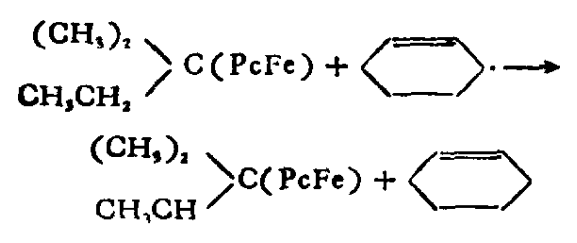

沈淑引薄恕群寿涵森 群许整君 (中国科学院感光化学研究所, 北京)

陈德文

(中国科学院化学研究所, 北京)

\title{
硅肺发生机制的研究
}

本文先以离子选择电极发现大鼠在硅肺 发病过程中, 肺游离钻离子浓度 $\left(\left[\mathrm{Ca}^{2+}\right]\right)$ 显 著升高; 后用荧光光谱、 ${ }^{4} \mathrm{Ca}^{2+}$ 示踪、等离子 光谱、拉曼光谱和 NMR 谱等实验手段, 探 讨了 $\left[\mathrm{Ca}^{2+}\right]$ 和高的过程及其对硅肺发生的 作用, 并分析了 $\alpha$-石英和无定形二氧化硅在 致硅肺能力上显示出差异的化学本质.

主要结果如下:

(1) 发现在硅肺发生初期的过程中, 肺 $\left[\mathrm{Ca}^{2+}\right]$ 在染尘后第 $3.5 \mathrm{~d}$ 就显著升高; 随后 随时间增加而增加, $60 \mathrm{~d}$ 后变化趋于平稳, 表示肺 $\left[\mathrm{Ca}^{2+}\right]$ 与硅肺发病存在着对应关系; 肺游离 $\left[\mathrm{Ca}^{2+}\right]$ 升高主要来源于肺泡巨噬细 胞内线粒体膜结合 $\mathrm{Ca}^{2+}$ 的释放.

（2） $\alpha$-石英致硅肺能力比无定形二氧化 硅强的重要原因是: (a) $\alpha$-石英表面硅羟基上 $\mathrm{H}^{+}$的离解度较高; (b) $\alpha$-石英表面 $>\mathrm{Si}-\mathrm{O}^{-}$ 基团整齐排列,对膜蛋白等的正极性基团 $\left(N^{+} H_{3}-R^{\prime}\right.$ 或 $\left.N^{+}\left(\mathrm{CH}_{3}\right)_{3}-R^{\prime \prime}\right)$ 的结合力 强. 原因 (a) 使 $\alpha$-石英离解出大量的 $\mathrm{H}^{+}$, 取
代巨噬细胞膜上结合的 $\mathrm{Ca}^{2+}$, 膜结合 $\mathrm{Ca}^{2+}$ 的 减少导致细胞内 $\mathrm{Ca}^{2+}$ 外流, 线粒体放出 $\mathrm{Ca}^{2+}$; 原因 (b) 使 $a$-石英对巨噬细胞膜相互 吸附力强, 膜上吸附的 $a$-石英量多。(a) 和 （b）共同作用可能是导致巨篍细胞损伤的原 因.

（3）硅肺形成后，血清中可溶性二氧化 硅含量显著升高, 说明 $\boldsymbol{\alpha}$-石英在硅肺发病过 程中溶解; 肺中 $\mathrm{Ca}, \mathrm{Fe}, \mathrm{Mg}$ 和 $\mathrm{Si}, \mathrm{P}$ 含量同 时并增,与如下化合物的生成相对应:

$\mathrm{MgCa}\left[\mathrm{Fe}_{3}^{(\mathrm{III})} \mathrm{Fe}_{3}^{(\mathrm{III})}(\mathrm{OH})_{3} \mathrm{Si}_{10} \mathrm{P}_{2} \mathrm{O}_{33}\left(\mathrm{OH}_{2}\right)_{2}\right]$.

（4）硅肺发生过程中, 前段脑 $\left[\mathrm{Ca}^{2+}\right]$ 有 一个由降低到升高的过程; 除染尘后 $3.5 \mathrm{~d}$ 观察到大鼠肺 $\left[\mathrm{K}^{+}\right]$显著降低外, 肝、脑、肾 和血清中 $\mathrm{K}, \mathrm{Fe}, \mathrm{Mg}$ 和 $\mathrm{P}$ 等元素含量在染 尘后均无明显变化.

$$
\begin{gathered}
\text { 毛延 陈荣三戴安邦 } \\
\text { (南京大学配位化学研究所) } \\
\text { 张祖暄 } \\
\text { (南京大学医学院) }
\end{gathered}
$$

\section{龙葵阿特拉津抗性基因向大豆叶绿体基因组的 转移及在转基因植株中的表达}

阿特拉津等均三氮苯类除草剂与叶绿体 类荛体膜上分子量为 $32 \mathrm{kD}$ 的蛋白质结合, 抑制了光系统 11 电子传递链中稳态原初与 次级电子受体间传递电子, 影响光合作用过 程. 对编码 $32 \mathrm{kD}$ 蛋白质的 $\mathrm{pSbA}$ 基因曾
有不少研究报告, 但将其抗性基因导入植物 叶绿体基因组尚末见到明确报道. 我们曾 从龙葵 (Solanum nigrum) 阿特拉津抗性生 物型中分离得到了含 $\mathrm{pSbA}$ 基因的叶绿体 DNA 片段，并分析了该基因的核苗酸序列. 
本文主要报道将抗性基因导人大至的结果.

选用夏大豆 (Glycine max) 新品系 83117 作受体植物（系中国农科院作物所大豆 室选育并提供)。在开花后一天内用自制微 量注射器将抗性基因 DNA 液注人子房 内. DNA从 pSB135 质粒中提取, 该质粒 含龙䓵抗性基因的叶绿体 DNA 片段, 将 质粒 DNA 溶于 pH7.6 的 TE 缓冲液中, 浓度为 $100 \mu \mathrm{g} / \mathrm{ml}$, 每个子房注射 $2 \mu 1$ 溶 液. 另外注射不含 DNA 的 TE 缓冲液作 为对照. 经注射得到的种子第二年种于大 田, 在开花期对单株进行了鉴定. 在对叶片 梌抹阿特拉津的鉴定中，未注射抗性基因的 后代对 $6 \times 10^{-4} \mathrm{~mol} / 1$ 阿特拉津水溶液敏 感, 叶片馀药液后很快出现褐色斑点, 然后变 黄、枯蒌, 6-10天后脱落. 三出复叶中 2 片 涂药小叶脱落, 有的末涂药小叶也一起脱落. 在注射抗性基因的第一代植株中，出现了涂 药后叶片生长正常的植株, 其叶色及光合作 用功能正常, 表现出对阿特拉津的抗性. 对 注射抗性基因后第一代 29 株的鉴定, 有 7 株 表现抗性. 未注射抗性基因的 53 株均为敏 感型. 利用荧光诱导动力学检测方法鉴定了 光系统 II 电子传递情况. 多次测定的结果表 明，在注射抗性基因的后代中出现了既有快 上升又有谩上升成分的诱导曲线. 说明电子
传递情况基本正常。末注射抗性基因的后 代，其诱导曲线只表现快上升成分，失去了僈 上开成分. 说明电子传递过程中断.

对用上述方法检测表现抗性的植株进行 了分子鉴定. 用在制备 pSB135 质粒时做载 体的 pBR 322 DNA 做探针(因为编码抗性 型与敏感型 32kD 蛋白质的基因只有一个核 苷酸之差,直接用 $\mathrm{pSbA}$ 基因做探针,不能测 出外源基因导人与否). DNA 点杂交放射性 自显影结果表明, 在 2 株表现抗性的植株叶 片叶绿体 DNA 中确实含有 pBR 322 DNA 的顼序，与探针杂交出现了明显的阳性反应. 而注射 TE 的后代和未经注射的植株显示 阴性反应, 与 pBR 322 DNA 没有同源性. 根据自显影放射性强度推断: 显示抗性的 2 个植株中, 每个叶绿体 DNA 基因组里约有 一个或略低于一个拷贝的外源 DNA 分子.

在温室中对少数子二代植株进行了初步 鉴定，表型和分子鉴定结果表明抗性基因可 以遗传. 这方面的研究正在深人之中.

刘伯林 岳绍先 (中国农业科学院作物育种裁培研究所, 北京) 胡乃壁 本小兵 翟文学 本诺 朱荣焕朱立煌 (中国科学院遭传研究所, 北京) 毛大璋 周佩珍 (中国科学院植物研究所, 北京) 